\title{
INSTITUTIONAL COMPETITION
}

\author{
EDWARD A. ROSS
}

University of Wisconsin

The first impulse of any organization or institution on the appearance of a serious competitor is to destroy competition. The "trust" regularly cuts the prices of its products to a point below cost of production in localities in which an "independent" seeks to sell. A shipping combine will have "fighting ships" which are called into play when a new steamship line enters their trade. As soon as the competitor announces a sailing date the combine advertises a steamer to sail on or near this date and offers a freight rate below the actual cost of carriage. In this way the competitor is prevented from securing a cargo.

The highest social class hobbles by minute sumptuary regulations the classes which aspire to come up abreast of it. In feudal Japan, for example, one might not use his money as he pleased. The farmer, craftsman, or shopkeeper could not build a house as he liked or procure himself such articles of luxury as his taste might incline him to buy. The richest commoner might not order certain things to be made for him, might not imitate the habits or assume the privileges of his betters. Although urged on economic grounds, sumptuary restrictions are doubtless intended to protect the monopoly of prestige by the higher social orders.

The spread of anti-slavery feeling among the producing people of the North during the generation before the American Civil War was due to their perception that slavery is a menace to the free-labor system. In accounting for the early abolition of slavery in Massachusetts John Adams remarks: "Argument might have had some weight . . . . but the real cause was the multiplication of laboring white people who would not longer suffer the rich to employ these sable rivals so much to their injury."

Monogamic marriage, tolerant enough toward monastic and Shaker celibacy, which put yet greater strain on human nature, 
suppresses as a dangerous rival every laxer form of sex relation"free love," the "complex marriage" of the Oneida community, Mormon polygamy, etc. Nor has it acknowledged any right of groups of men and women to order their relations according to their own convictions and judgment.

After representative government with its inevitable strife of parties has been established the parties controlled by the propertied strive to crush the rising party which asserts working-class interests. To avoid meeting it in the arena of public discussion they hypocritically denounce it as anti-patriotic and subversive, a movement with criminal aims led by scoundrels and assassins, which is not entitled to the belligerent rights of a legitimate political party but deserves only to be stamped out by suppressing its propaganda and hounding its leaders. Thus was outlawed the socialist party in Germany during Bismarck's ascendancy. On the other hand, labor organizations oppose all proposals looking to state health-insurance, because many of them have developed insurance schemes of their own and they fear lest their power to hold their members will be weakened under compulsory state insurance.

The whole history of religious persecution is the history of an organization trying to establish itself as a monopoly by ruthless destruction of the spokesmen of competing doctrines and movements. In Diocletian's time Roman religious beliefs were weak while the Christian beliefs were vigorous and spreading. In desperation the old system made a ferocious attempt to exterminate all Christians. A thousand years later the church stamped certain sects out of existence and strangled heresies in the cradle. Says Coulton:

... . What Darwin took at first for a smooth unbroken grass land proved, on nearer examination, to be thick-set with tiny self-sown firs, which the cattle regularly cropped as they grew. Similarly, that which some love to picture as the harmonious growth of one great body through the Middle Ages is really a history of many divergent opinions violently strangled at birth; while hundreds more, too vigorous to be killed by the adverse surroundings, and elastic enough to take something of the outward colour of their environment, grew in spite of the hierarchy into organisms which, in their turn, profoundly modified the whole constitution of the Church. If the mediaeval theory and practice of persecution had still been in full force in the eighteenth century in England, nearly all the best Wesleyans would have chosen to remain within the Church 
rather than to shed blood in revolt; and the rest would have been killed off like wild beasts. The present unity of Romanism so far as it exists, is due less to tact than to naked force. ${ }^{\mathrm{x}}$

Instructive is the change of front of the church with respect to the Franciscans. The religion of poverty and love propagated by Francis of Assissi took possession of the whole church. The most beautiful chants of the. Middle Ages and the greatest sermons originated among the Franciscans and the Dominicans closely related to them. New life was given to art and scholarship. All the great scholars of the thirteenth century-Thomas of Aquinas, Bonaventura, Albertus-were of the begging orders.

But the church which had granted authority to St. Francis and established the Little Brothers of the Poor as a monastic order turned against it when the ideal of poverty spread so far as to menace her power and riches. She declared what the Franciscans were preaching about the poverty of Christ and the Apostles to be heresy and demanded submission. All the "spiritual" Franciscans were condemned as heretics. Cardinals who still defended the ideal of poverty a few years before so popular fell into disgrace. There was a bitter struggle, but at the end of the fourteenth century the worldly church had crushed the propaganda of the poverty ideal. As a result the monastic orders lost in inspiration and influence and by the time of the Renaissance monasticism had fallen into "laziness and worthlessness."

In I660 the English Episcopal church became established and entered upon the same policy of persecution of which formerly it had been the victim. In 1662 the Act of Uniformity was passed enforcing the use of the amended Book of Common Prayer. In I664 the Conventicle Act made illegal all meetings for worship except according to the church. In 1665 an act was passed forbidding Nonconformist ministers to approach a borough. Not until r689 was the endeavor to crush the sects abandoned.

The Puritan theocracy in New England in its persecution of Antinomians, Baptists, and Quakers showed a like ruthless determination to crush every movement which might bring about its overthrow.

'From St. Francis to Dante, p. 40.

'See Harnack, The Evolution of the Monastic Ideal. 
In case the rival cannot be destroyed one seeks to withdraw from competition, just as an army which cannot whip the enemy retires behind fortifications. The rulers of Japan, discovering early in the seventeenth century that the Jesuit missions were disintegrating a society founded on communal custom and filial piety, slew the native Christians, expelled all foreigners save the Dutch traders, who were confined to a 3 -acre isle, made it a capital offense for any Japanese to leave Japan, destroyed all vessels capable of long voyages, and attacked any European ships entering a Japanese port, excepting the vessels of the Dutch company. In like manner China in the sixteenth century sought to isolate itself from foreign influences.

In the third quarter of the last century, it became clear that the common American standard of living could not possibly survive the competition of the Chinese coolies' standard of living. The friends of the American standard finally erected a barrier against the oriental standard in the form of the Chinese Exclusion Act. The wide support of this policy outside the manual laboring class shows that it was the reaction of a threatened standard rather than of interested American wage-earners.

The endeavor of Chinese officials to restrain the Christian missionaries from going about preaching and teaching in China, as well as the violences which from time to time they have deliberately stirred up against them, sprang from the fear of the literary and official class lest the ideas the missionaries introduce should make it harder to maintain their system of governing and exploiting the masses.

A state with few economic opportunities open cannot hope to attract immigrants and therefore by every means in its power it binds its citizens to it. It argues "Once a Batavian always a Batavian," limits emigration or expatriation, cultivates the goodwill of its nationals whithersoever they may wander and frowns upon their naturalization in another state.

A church that cannot crush its competitors claims special protection from the state. In South America until recently the state has been used to protect the religious monopoly of the Roman Catholic church. Only since $\mathrm{I} 86_{5}$ in Chile have non-Catholics 
been permitted "to practice their religion inside private buildings belonging to them." Until I907 the law decreed that any person conspiring "to establish in Bolivia any other religion than that which the Republic professes, namely, that of the Roman Catholic Apostolic church" is a traitor. The constitution of Peru declared "The Nation professes the Roman Catholic Apostolic religion; the State protects it and does not permit the exercise of any other." Not until I9I 5 was the last clause abrogated.

Throughout Spanish and French America the church secured and kept in its hands the control of schools, burial grounds, marriage, and poor relief. Until lately Russian Orthodoxy, unable by ferocious persecution to uproot the dissenting sects, had the state punish with great severity any proselyting among the Orthodox, whereas the latter might proselyte as they pleased.

If the state will not shield her, the church that shrinks from meeting competition builds for herself a citadel within which she can continue her life untroubled by the assaults from the outside world. The early church encouraged mixed marriages in the serene confidence that the Christian would convert, rather than be converted by, the pagan mate. But an edict of Louis XIV forbade marriage with heretics, because of the "continual temptation of perversion." An expanding church does not admit very young members and is willing that the children of its members should freely choose their religion; but a church hard pressed hopes to forestall the judgment of its young people by incorporating them at an early age and requires its members to rear their children straitly in the faith. It conducts its young through a tunnel of church schools and societies, lit by church lamps, instead of letting them into the broad daylight of the public school, the social settlement, the social center, and the public playground.

Great attention, too, is given to hedging the minds of the adult faithful. The church forbids them to read certain periodicals, patronize certain libraries, see certain plays, or follow certain university courses. Such maternal nervousness is a sure sign that the church, feeling the Zeitgeist to be alien, counts on surviving by holding on to her people rather than by winning new converts. 
The college loath to modernize its curriculum and methods follows the same tactics. It cultivates assiduously its alumni and appeals to them to send their sons to "dear old Bokhara." Conversely, an institution like the West Point Military Academy is held to an antiquated type of military education because the "West Pointers" who send their sons there want the school to remain as they knew it.

Oxford University, in Adam Smith's day, was careful to curb competition lest it disclose weaknesses. Students enrolled in a college might not leave it for another without first securing permission of the college they sought to abandon. Academic discipline appeared to have the purpose of making the students attend worthless, distasteful lectures and behave toward the professor, whether he performed or neglected his duty, as if he had performed it with the greatest diligence and ability. ${ }^{\mathbf{r}}$

In the face of the growing interest in new studies, such as natural science and social science, the classics intrench themselves in the college curriculum as "required subjects," while the new attractions are kept in the inferior status of "elective subjects."

A party menaced by a new political movement it dares not meet in the open gets the weather gage by a law excluding from the official ballot a party which has not received a specified percentage of the ballots cast at the last election.

In business a means of holding competitors at bay is the "factors' agreement" which binds the dealer to handle only the goods of a certain producer. Again, an organization may require of the dealer the handling of articles upon which the patents have expired, as a condition of obtaining other articles, or the handling of a certain article or line of articles as a condition of the handling another article or line of articles.

A third means of surviving competition may be called constrained adaptation.

The government-led Westernization of Japan was not essentially a conversion to occidental thought but the reluctant taking over of certain Western institutions and policies in order to save Japan from absorption by some Western power.

'See Smith's Wealth of Nations, II, 348-49. 
It can hardly be doubted that the Counter-Reformation within the church at the Council of Trent was an adaptation forced by competition.

In China the activity of the Christian missionaries is forcing the native faiths to assume higher forms in order to survive. Chinese scholars are reading into the Confucian classics elevated moral ideas which they have unconsciously imbibed from Christian literature. There is, indeed, a movement which frankly calls itself "Confucio-Christianity." In some parts, under the spur of missionary competition, the Confucians band together and send out wandering gospellers of their own to spread the doctrines of the sage at fairs and festivals. ${ }^{x}$

The Ceylonese Buddhists speak of the "incarnation" and the "immaculate conception" of Buddha and comfort the dying by assuring them that the Lord Buddha will presently receive them into his arms. The Buddhists of Japan besides sending out missionaries of their own have adopted various methods of their Christian competitors. They have stated times for preaching. They have pastoral visitation, street preaching, Sunday schools, prison and army chaplains, and special organizations for young men, women, and children. They maintain charities, push temperance, and set up schools.

Partly from the soaking in of Christian ideas and partly as tactics for surviving missionary competition Hinduism is honeycombed with reform movements and crude doctrines and rites are rapidly being sloughed off.

Owing to competition among themselves American religious denominations have had forced upon them changes distasteful to the ruling element. The "amusement" clause of the Methodist Book of Discipline has in many places become a dead letter because its enforcement would be a serious handicap in competition with less strict churches. The success of the undenominational Young People's Christian Endeavor Society caused large denominations to organize young people's societies of their own. In like manner the churches develop "institutional" or social, or recreative, features, not because their members want them, but in order to attract or

${ }^{x}$ See Ross, The Changing Chinese, pp. 256-57, 279. 
hold the young people, the men, or the unchurched. President Vincent says:

The prevalent manifestations of goodfeeling, brotherliness, and cooperation between ministers and churches are in large measure unconscious forms under which they compete for the approval of a public opinion which demands tolerance, friendliness, and unity. The minister and the church who hold aloof quickly feel the displeasure of the community and distinctly lose caste. ${ }^{x}$

Competition may constrain an institution to adopt a line which lies quite outside its proper sphere. Early in the nineteenth century English Nonconformists founded the British Schools Society. Not to be outdone the established church, which hitherto had utterly ignored elementary education, entered upon the work of promoting schools. But it was natural enough for the Nonconformists to make a special effort in the direction of education because their adherents were largely of the English lower orders, which were at that time very illiterate. The established church, however, was in no such case and took upon herself altogether too heavy a burden of education. In the end a situation developed which led to the state taking over all the church schools.

The modern socialist movement has forced conservative institutions to concern themselves with the material welfare of the masses. In the 7o's of the last century in order to check Lassalle's movement, Bishop Kettler of Mayence organized in Rhenish Prussia Christian trade unions which spread to Germany and Austria. In Belgium the socialists, in accordance with their principles, organized co-operative banks among the poor. In order not to lose influence over them the church started co-operative banks of her own. In the same way co-operative credit associations have been organized in Quebec in connection with the church.

No doubt the advanced social program of the Federal Council of Churches in Christ was adopted by most of the Protestant churches reluctantly and only because it was realized that "something must be done to win back the workingmen."

The whole German system of social insurance was in the first place urged by the Socialist party. Bismarck and his Junkers

${ }^{x}$ Methodist Revierw, January, 1906, p. 75. 
hated the socialists and cared little for the welfare of the working class, but they took over these alien policies in order to make German wage-earners proof against socialism.

When wage-earners are enfranchised or organize themselves, political parties officered and run by the propertied class vie with each other in wooing them. Whether they shall gain anything from this competition depends upon their intelligence. The politicians run their man as the "log cabin" candidate, court labor with genial handshaking and barbecue, appease labor leaders with political jobs, scatter promises they do not intend to fulfil, give their policies a labor flavor (high tariff urged as the "protection of American workingmen"), pass measures which they know the courts will annul as unconstitutional, throw labor a few sops, or offer substantial benefits while at the same time providing capitalists with new benefits along other lines. Only in case all this does not avail is it necessary for the party to lend itself seriously to realizing a working-class program.

The competition of young American commonwealths for immigrants contributed to the spread of democracy in the United States by promoting the extension of the suffrage and the early adoption of a system of public education. The competition of ambitious cities for residents or factories obliges them to adopt policies respecting saloons, prostitution, parks, boulevards, schools, police, handling of labor troubles, etc., which may be wormwood to the majority.

Universities are loath to change, so that their adaptation to new conditions is usually forced by competition. The universities of the seventeenth century, incrusted still in scholasticism, adopted the principle of freedom of inquiry which prevailed in the newly founded scientific academies - only because in no other way could they attract the best scholars of their day. Americans are fortunate in having two types of university-endowed and state. Their competition for professors broadens academic freedom while their competition for students tends to modernize the curriculum by introducing such new subjects as economics, sociology, business administration, and journalism. The catering of corporate universities to the prejudices of possible donors would hamper gravely 
the teaching of the social sciences, were it not that they have to meet the competition of the liberal state universities.

In public institutions and in private institutions there are elements of strength and elements of weakness, but they are not identical in the two types. Accordingly if the two types are brought into honorable competition within the same field each is stimulated to develop the kind of strength the other has, along with its own kind of strength, and to rid itself of the weaknesses peculiar to it. Fortunate therefore is the society which has both public and private high schools, both state and corporate universities, both state and private forestry, both state and commercial insurance service, both parcel post and express companies, both community and private agencies of poor relief, and both state and philanthropic institutions for dependents. In order that there may be true competition there should be no alliance of any sort between private societies or foundations and the government. The government should neither subsidize them nor be subsidized by them, but each should go ahead on its own resources and show the best it can do for the people.

Of course under constraint an institution adapts its manners and methods to the situation rather than its principles or policies. Instance the suppleness of the Jesuits who become "all things to all men," winning men of the world with their polish and lovers of truth with their zeal for science. Instance a Tory university reeking with oil-trust money which builds a huge stadium and dazzles young people with the splendor of its athletics. A political party camouflages its aristocratic principles with leaders or candidates who are extra-approachable and democratic in manner. The Russian bureaucracy tried to hold in check the radical labor movement by sending out its own secret agents to organize labor unions.

Finally an institution eludes competition by specializing. This is like the ingenious business man who keeps ahead of his imitative competitors by continually differentiating his product so as to meet a special demand. As people get used to it and more and more demand it, it passes from specialty into staple. But he has a fresh differentiation ready, slight, perhaps, but significant enough 
to awaken a new demand or a modification of the original demand -another specialty.

Thus a college may snap its fingers at rivals offering courses in commerce and journalism and keep its halls filled by offering the best-framed and best-taught classical course of study. When yellow journalism seems to be carrying all before it, some journals save themselves by excluding blare and flare and offering the judicious a soundproof retreat amid the howling of Bedlam. Until lately the British navy refused to enter the common arena of competition among the professions. No one could become a cadet without a recommendation from some relation or friend of the family in the navy. This restriction might seem to limit fatally the talent the navy drew upon. But at a time when all such barriers about the professions were coming down, the prestige accruing to the navy from its social exclusiveness may really have operated to supply it with more than its fair share of talent.

A church which in its attitude toward science, morals, and social work is out of harmony with its time is not doomed to languish. It may win by specializing in religious aesthetics. With dusky and mysterious interiors, magnificent mosiacs, wonderful Gregorian music, forests of lighted candles, and domes blue with incense smoke; it may attract those who are sensuous or mystic in temperament, and make headway while more rational faiths are losing ground.

So far we have considered the behavior of the established when threatened by the new. Now the new has its policies, too, but they will be quite other than the four I have described. Because it is young and weak, it will not assault its established competitor with intent to destroy. It cannot withdraw from competition because it has no intrenchments to withdraw to. It is not constrained to adapt itself because it is already adapted to the time that sees its birth. If it specializes there is no competition at all between it and the established.

On the other hand the new follows tactics of its own which are not open to the established. Unlike its competitor it can court support by making extravagant claims and promises. The old church, party, or education is limited in its promises by its past performance; but there is no such check on the claims of the young 
aspirant and so it gives free rein to its imagination. The new remedy sets up as a cure-all. The untried reform poses as a panacea. When the Fourier phalanx, co-operative production, the single tax on land values, the "natural" system of learning foreign languages, or the monitor system, is first proposed, it is possible to paint glowing pictures of the blessings it will bring.

It is logical that the new should often strive to arrest public attention by sensationalism. The established has the prestige of antiquity and possession. The new covets prestige but it must gain it by other means. The new-rich in order to break the spell exercised by old families sets a pace in extravagance and ostentation which amazes and which the former social arbiters cannot stand. The leaders of new departures in art or literature excite curiosity and awe by long hair, flowing ties, unfashionable cut of dress, bizarre actions, and studied unintelligibility. Joseph Smith, the founder of Mormonism, made an immense sensation with his story of the Angel with its inscribed plates of gold. New religious movements are much readier than the old with claims of signs and wonders. Nor is charlatanry confined to the unworthy new. Even champions of the worthy new may stoop to it.

The new appeals to the more easily aroused demands of human nature. The demand for freedom is one of these and hence the new holds out the lure of release from some form of restraint. Jesus proclaimed, "My yoke is easy and my burden is light." Paul preached "Christ hath redeemed us from the curse of the law." Luther taught that the Gospel brought sweet relief from the onerous requirements of the Law. The Protestants offered Christians freedom from "prelacy." The Anabaptists threw off the gyves of private property and held "prophecy" open to all. Quakers rejected the sacraments and a paid clergy. The Free Methodists offered a free course for the expression of religious feeling. Philosophic individualism makes great headway for a time, and the doctrines of anarchism have a seductiveness of their own. The teaching of the superiority of the artist to all conventions including the Ten Commandments will always meet with response. "Free verse" is a rallying cry, while symbolism is welcomed as loosing the artist from the trammels of the actual. The "free election of studies" is a winning cry for an assault on the fixed curriculum. 
Freedom is, however, not the only winning appeal of the new. Aside from real merit, ritual, secrecy, and exclusiveness are other means of gaining a following.

Thanks to these tactics, a new thing without merit may triumph over the time-tested old if the plane of popular intelligence be low. Among the ignorant, valuable institutions may be shaken by the imprudent and blatant competition of charlatans, fanatics, and false prophets. For a while people may turn from the hard-won and age-sifted truth to follow bubble promises and irridescent sophisms. That which is suited to man's deep and lasting needs may be abandoned for that which chimes with his fitful and passing desires.

When, however, the plane of intelligence is high, the competition of the new is to be welcomed, because it is chiefly competition that keeps institutions adapted to the conditions they face and the people they serve. Without this spur the institution stands still or even degenerates. Since this is so, no institution ought to be shielded from competition by any special privilege or advantage. The youthful sect, party, college, doctrine, or ideal ought to have the same freedom to agitate, advertise, proselyte, and organize that the established enjoys. Moreover, individuals must be free to detach themselves from old organizations without unreasonable forfeiture and join new ones or none at all. Inter-party migration tends to liberalize parties; inter-denominational migration to liberalize churches; inter-university migration to liberalize universities; inter-state migration to liberalize governments.

An institution that has the children of its members for nothing need not cater to them and, if it will content itself with such following, it may petrify in its tracks. It is not good, therefore, that the sons should inherit creed, party allegiance, college allegiance, local allegiance from their fathers; they should choose in freedom. The parent that fastens unescapable bonds upon the child before it has reached the age of choice confiscates the child's personality.

If, instead of inheriting their adherents, organizations had to win them, they would accommodate themselves to today. The contrasts between organizations would connect less with differences of origin and history and more with the actual contrasts of type in contemporary society. In religion, for example, Methodists and Catholics, Friends and Christian Socialists, Dunkers and 
Salvation Army, would, no doubt, find each a type they were best suited to, but certainly some of the one hundred and fifty sects in the United States rooted in distant European conditions or remote centuries would vanish from the scene.

The competition for public favor between parties, sects, schóols, universities, governments, manners, and ideals produces democratic society. The competition of manners for adoption makes them direct and expressive instead of stiff and formal. The competition of ideals for favor humanizes them and brings them into accord with the real soul of man. As organizations and institutions compete, their line of development becomes subject to the general trend of opinion and feeling. With status, institutions make the character of their people; with competition, the people make the character of their institutions. When everyone chooses his religion instead of inheriting it, the people make the religion instead of the religion making the people. 